\title{
Seed coat diversity in some tribes of Cucurbitaceae: implications for taxonomy and species identification
}

\author{
Samia Heneidak ${ }^{1}$ and Kadry Abdel Khalik ${ }^{2,3, *}$
}

Received: August 2, 2014. Accepted: October 8, 2014

\begin{abstract}
To evaluate their diagnostic value in systematic studies, seed coat morphology for 16 taxa from 11 genera of Cucurbitaceae were examined using stereomicroscopy and scanning electron microscopy. The taxa included representatives of the tribes Benincaseae, Bryonieae, Coniandreae, and Luffeae in order to evaluate their diagnostic value in systematic studies. Macro- and micromorphological characters of their seeds are presented, including shape, color, size, surface, epidermal cell shape, anticlinal boundaries, and periclinal cell wall. The taxonomic and phylogenetic implications of seed coat micromorphology were compared with those of the available gross morphological and molecular data. Seed character analysis offered useful data for evaluating the taxonomy of Cucurbitaceae on both intrageneric and tribal levels. Monophyly of the tribes Bryonieae, Coniandreae, and Luffeae was supported. Moreover, these analyses supported previous biochemical and phylogenetic data, indicating that distinct lineages are present within the tribe Benincaseae, that this tribe is not monophyletic, and that the subtribe Benincasinae is highly polyphyletic. A key is provided for identifying the investigated taxa based on seed characters.
\end{abstract}

Keywords: Cluster analysis, PCO, scanning electron microscopy, seed coat, tribal classification, UPGMA

\section{Introduction}

Cucurbitaceae is a widespread family of $118-122$ genera and 900 species (Simpson 2010) of monoecious or dioecious herbs and erect shrubs. The family is mainly distributed in tropical and subtropical regions with relatively few species reaching the temperate regions of the world. The aerial parts of all species are sensitive to frost. The family also includes a few shrub species (e.g., Acanthosicyos horridus) and lianas with climbing or trailing, woody perennial stems. The family includes economically important food crops such as Citrullus lanatus and Nakai (watermelon), which represents approximately $10 \%$ of the world vegetable production (Vossen et al. 2004), Cucumis melo (melons), Cucumis sativus (cucumber), Cucurbita pepo, and other Cucurbita species (squash and pumpkins). Luffa are used as sponges, and Lagenaria siceraria, bottle gourd, are used as vessels in African and Asian cultures (Whitaker \& Davis 1962; Erickson et al. 2005; Clarke et al. 2006). The leaves and shoots of many species are finally boiled and eaten as a vegetable in both Africa and Asia (Okoli \& Onofeghara 1984 ), and many species play a role in folk medicine.

Hooker (1867) divided Cucurbitaceae into 68 genera and eight tribes. These tribes are Cucumerineae, Abobreae, Elaterieae, Sicyoideae, Gomphogyneae, Gynostemmeae, Zanonieae, and Fevilleeae. According to Jeffrey (1980;
1990), Cucurbitaceae is subdivided into two well-defined subfamilies, Zanonioideae and Cucurbitoideae, and eight tribes represent various degrees of circumscriptive cohesiveness. The subfamily Cucurbitoideae has the most important cucurbit crops, such as Cucumis, Cucurbita, and Luffa. Eleven tribes have been more recently recognized with 125 genera and approximately 800 species (Jeffrey 2005; Wilde \& Duyfjes 2006 a; b; c; Kocyan et al. 2007). However, Schaefer \& Renner (2011) recognized 97 genera and $940-980$ species subdivided into 15 tribes. A new classification system (Schaefer \& Renner 2011) resulted in the replacement of many subtribes and the elevation of others to the tribal rank. For instance, subtribe Luffinae, previously a member of Benincaseae, was elevated to the tribal level.

The tribe Benincaseae, currently with two subtribes (Benincasinae and Cucumerinae) and 35 genera, is the largest tribe of Cucurbitaceae. Molecular phylogenetic analysis by Decker-Walters et al. (2004) revealed a deviation from the former morphological classification (Jeffrey 1990). However, the phylogenetic classification of the tribe Benincaseae was examined by Kocyan et al. (2007), who demonstrated that Benincaseae is not monophyletic and that subtribes Benincasinae and Cucumerinae are highly polyphyletic.

Achigan-Dako (2008) investigated the phylogenetic analysis of 68 species and subspecies of the tribe Beninca-

\footnotetext{
${ }^{1}$ Botany Department, Faculty of Science, Suez University, Suez, Egypt

${ }^{2}$ Biology Department, Faculty of Science, Umm-Al-Qura University, Mecca, Saudi Arabia

${ }^{3}$ Botany Department, Faculty of Science, Sohag University, Sohag, Egypt

*Author for correspondence: kadry3000@yahoo.com
} 
seae based on 127 nuclear rDNA internal transcribed spacer region (ITS) sequences and showed that the subdivision of the tribe into the subtribes Benincasinae and Cucumerinae was not supported. Moreover, they supported the elevation of Luffinae to the tribal rank.

Rizk (2001) studied the morphology and cytotaxonomy of 27 Egyptian taxa of cultivated varieties and landraces belonging to three genera of Cucurbitaceae (Cucumis, $\mathrm{Cu}$ curbita, and Luffa), six species, and five subspecies. He found that fruit characters were a good taxonomic tool when combined with other vegetative characters at the varietal level.

During the last decades, SEM has been applied to the morphological study of seeds and small fruits. Micromorphology and ultrastructural data have provided useful information concerning the evolution and classification of seed plants and have played an important role in the modern synthetic systems of Angiosperms (Heywood 1971; Abdel Khalik \& Maesen 2002).

Seed morphology provides a number of characteristics that are potentially useful for species identification, phylogenetic inference, and character-state evolution (Jobst et al. 1998; Johnson et al. 2004; Attar et al. 2007; Moazzeni et al. 2007; Mostafavi et al. 2013). Observations of many plant groups have shown that seed morphology and anatomic features are rather conservative, and hence taxonomically important (Barthlott 1981; 1984; Werker 1997; Abdel Khalik 2010; 2013; Abdel Khalik \& Hassan 2012; Hassan \& Abdel Khalik 2014).

Data are rather limited on the seed morphology of representatives from the different tribes of Cucurbitaceae, and a few seed shapes are unique, which may permit the assignment of fossil seeds to particular genera.

The aims of the present study were 1) to investigate the range of variability of seed characters in 11 genera (16 species) from some Cucurbitaceae tribes, 2) to use cluster analysis to elucidate the usefulness of seed characters to distinguish these tribes, and 3) to assess whether these results correspond to the systematics of the genera as proposed by Walters (1989), Jeffrey (2005), Achigan-Dako (2008), and Schaefer \& Renner (2011).

\section{Material and methods}

\subsection{Seed material}

Sixteen taxa belonging to 11 genera of Cucurbitaceae were analyzed. Some of the investigated seeds were collected from mature plants in Egypt and others were taken from herbarium specimens. A list of voucher specimens and localities is provided in Table 1. Only mature seeds were taken for investigation. The dried seeds were first examined by dissecting microscope (Olympus type $\mathrm{BH}-2$ ), and then 5-10 seeds from each taxon were selected to cover the range of variation. Seeds were mounted on stubs with double-sided adhesive tape and sputter-coated with gold for $5 \mathrm{~min}$ in an
S150A sputter coater (Edwards Ltd., England). The specimens were examined using a SEM-JEOL JXA840A Electron Probe Microanalyzer (JEOL Ltd, Japan), at accelerating voltages of $20-25 \mathrm{kV}$. All photomicrographs were taken at the SEM laboratory, National Research Centre, Dokki, Cairo, Egypt. The terminology used to describe seed shape, cell shape, and seed coat ornamentation followed that of Barthlott (1981; 1984), Abdel Khalik \& Maesen (2002), and Teppner (2004).

\subsection{Selection of coding characters}

The principles for selecting coding characters were the independency of the characters and their stability within the taxa analyzed (Stuessy 1990; Davitashvili \& Karrer 2010). Seeds provide several qualitative and few quantitative characters. Our focus was on the qualitative characters of seed micromorphology that were easy to detect. One quantitative character (character 6) was treated statistically as a qualitative characters.

\subsection{Analysis of seed data}

Twelve characters were measured for each species. Two types of analyses were performed with NTSYS-pc 2.02k software (Applied Biostatistics Inc., Setauket, New York, USA). Firstly, we performed a cluster analysis using the average taxonomic distance and UPGMA clustering (procedures SIMINT, SAHN, and TREE). To reduce the effects of different scales of measurement for different characters, the values for each character were standardized with procedure STAND according to the formula: $y I, S T D=(y i-A V G y i) / S T D y i$, where the default value in NTSYS-pc (STAND) for $y i=$ the value to be standardized, AVGyi = the average of all values for the character, and STDyi = the standard deviation. The cophenetic correlation coefficient between the distance matrix and the tree matrix was calculated to examine the goodness of fit of the cluster analysis to the distance matrix (procedures $\mathrm{COPH}$ and MXCOMP). Secondly, a principal coordinates analysis (PCO) was performed, using the product-moment correlation as a coefficient. The procedure SIMINT was used to calculate the distance matrix based on STAND data, and the procedures EIGEN, PROJ, and MXPLOT were used to perform the PCO.

\section{Results}

The seed morphological characters for the studied taxa of the family Cucurbitaceae are summarized in Table 2, and the stereomicroscopy and SEM images are presented in Figs. 1-4.

\subsection{Seed color}

The color of seeds is highly diagnostic and of systematic interest among taxa. The seed color varied from black in Luffa acutangula and L. cylindrica; black to brown in 
Table 1. List of taxa used in the study. A comparison of the most traditional (Walters, 1989) and a recent phylogenetic classification based on molecular data (Jeffrey, 2005; Achigan-Dako 2008; and Schaefer \& Renner 2011).

\begin{tabular}{|c|c|c|c|c|c|c|c|}
\hline $\mathbf{N}$ & Taxa & Voucher & Walters, 1989 & Jeffrey, 2005 & $\begin{array}{l}\text { Achigan-Dako and } \\
\text { Blattner (2008) }\end{array}$ & $\begin{array}{l}\text { Schaefer and } \\
\text { Renner (2011) }\end{array}$ & $\begin{array}{l}\text { Present } \\
\text { study }\end{array}$ \\
\hline 1 & $\begin{array}{l}\text { Acanthosicyos } \\
\text { horridus Welw. ex } \\
\text { Hook.f. }\end{array}$ & $\begin{array}{l}\text { Kew garden, } \\
\text { Millennium seed } \\
\text { bank, serial number: } \\
238530(\mathrm{~K})\end{array}$ & - & $\begin{array}{l}\text { Tribe: Benincaseae } \\
\text { Subtribe: } \\
\text { Benincasinae }\end{array}$ & $\begin{array}{l}\text { Tribe: Benincaseae } \\
\text { Subtribe: } \\
\text { Benincasinae }\end{array}$ & Tribe: Benincaseae & Group F \\
\hline 2 & $\begin{array}{l}\text { Bambekea racemosa } \\
\text { Cogn. }\end{array}$ & $\begin{array}{l}\text { Congo, Louis } 5.862 \\
(\mathrm{~K}) .\end{array}$ & - & $\begin{array}{l}\text { Tribe: Benincaseae } \\
\text { Subtribe: } \\
\text { Benincasinae }\end{array}$ & $\begin{array}{l}\text { Tribe: Benincaseae } \\
\text { Subtribe: } \\
\text { Benincasinae }\end{array}$ & Tribe: Coniandreae & Group A \\
\hline 3 & $\begin{array}{l}\text { Benincasa hispida } \\
\text { (Thumb.) Cogn. }\end{array}$ & $\begin{array}{l}\text { Tonga, Crosby } 71 \\
(\mathrm{~K}) \text {. }\end{array}$ & $\begin{array}{l}\text { Tribe: Benincaseae } \\
\text { Subtribe: } \\
\text { Benincasinae }\end{array}$ & $\begin{array}{l}\text { Tribe: Benincaseae } \\
\text { Subtribe: } \\
\text { Benincasinae }\end{array}$ & $\begin{array}{l}\text { Tribe: Benincaseae } \\
\text { Subtribe: } \\
\text { Benincasinae }\end{array}$ & Tribe: Benincaseae & Group F \\
\hline 4 & Bryonia alba $\mathrm{L}$. & $\begin{array}{l}\text { Turkey, Vezmis, } \\
\text { Near the village } \\
\text { Amasya, Baytop } \\
4670 \text { (E). }\end{array}$ & - & Tribe: Bryonieae & Tribe: Bryonieae & Tribe: Bryonieae & Group E \\
\hline 5 & Bryonia cretica L. & $\begin{array}{l}\text { Kew garden, } \\
\text { Millennium seed } \\
\text { bank, serial number: } \\
186380(\mathrm{~K}) \text {. }\end{array}$ & - & Tribe: Bryonieae & Tribe: Bryonieae & Tribe: Bryonieae & Group E \\
\hline 6 & Bryoniadioica Jacq & $\begin{array}{l}\text { Algeria, Beni } \\
\text { Saf,Davis } 51496 \text { (E) }\end{array}$ & - & Tribe: Bryonieae & Tribe: Bryonieae & Tribe: Bryonieae & Group E \\
\hline 7 & $\begin{array}{l}\text { Citrullus colocynthis } \\
\text { (L.) Schrad. }\end{array}$ & $\begin{array}{l}\text { Egypt, St. Katherine, } \\
\text { Heneidak s.n. (Suez } \\
\text { Fac. Sci. Herb) }\end{array}$ & $\begin{array}{l}\text { Tribe: Benincaseae } \\
\text { Subtribe: } \\
\text { Benincasinae }\end{array}$ & $\begin{array}{l}\text { Tribe: Benincaseae } \\
\text { Subtribe: } \\
\text { Benincasinae }\end{array}$ & $\begin{array}{l}\text { Tribe: Benincaseae } \\
\text { Subtribe: } \\
\text { Benincasinae }\end{array}$ & Tribe: Benincaseae & Group E \\
\hline 8 & $\begin{array}{l}\text { Citrullus ecirrhosus } \\
\text { Cong. }\end{array}$ & $\begin{array}{l}\text { Kew garden, } \\
\text { Millennium seed } \\
\text { bank, serial number: } \\
105064(\mathrm{~K}) \text {. }\end{array}$ & $\begin{array}{l}\text { Tribe: Benincaseae } \\
\text { Subtribe: } \\
\text { Benincasinae }\end{array}$ & $\begin{array}{l}\text { Tribe: Benincaseae } \\
\text { Subtribe: } \\
\text { Benincasinae }\end{array}$ & $\begin{array}{l}\text { Tribe: Benincaseae } \\
\text { Subtribe: } \\
\text { Benincasinae }\end{array}$ & Tribe: Benincaseae & Group C \\
\hline 9 & $\begin{array}{l}\text { Citrullus lanatus } \\
\text { (Thunb.) Matsum. } \\
\text { \& Nakai }\end{array}$ & $\begin{array}{l}\text { Kew garden, } \\
\text { Millennium seed } \\
\text { bank, serial number } \\
: 140661(\mathrm{~K}) \text {. }\end{array}$ & $\begin{array}{l}\text { Tribe: Benincaseae } \\
\text { Subtribe: } \\
\text { Benincasinae }\end{array}$ & $\begin{array}{l}\text { Tribe: Benincaseae } \\
\text { Subtribe: } \\
\text { Benincasinae }\end{array}$ & $\begin{array}{l}\text { Tribe: Benincaseae } \\
\text { Subtribe: } \\
\text { Benincasinae }\end{array}$ & Tribe: Benincaseae & Group C \\
\hline 10 & $\begin{array}{l}\text { Diplocyclos palmatus } \\
\text { (L.) C. Jeffrey }\end{array}$ & $\begin{array}{l}\text { Nepal, } \\
\text { Sankhuwasabha, } \\
\text { Koshi Zone, Long et } \\
\text { al. } 41 \text { (E). }\end{array}$ & - & $\begin{array}{l}\text { Tribe: Benincaseae } \\
\text { Subtribe: } \\
\text { Benincasinae }\end{array}$ & $\begin{array}{l}\text { Tribe: Benincaseae } \\
\text { Subtribe: } \\
\text { Benincasinae }\end{array}$ & Tribe: Benincaseae & Group C \\
\hline 11 & $\begin{array}{l}\text { Lagenaria sphaerica } \\
\text { (Sond.) Naud }\end{array}$ & $\begin{array}{l}\text { South Africa, } \\
\text { Ingwaruma, } \\
\text { KwaZulu-Natal, } \\
\text { Pooley } 509 \text { (E). }\end{array}$ & $\begin{array}{l}\text { Tribe: Benincaseae } \\
\text { Subtribe: } \\
\text { Benincasinae }\end{array}$ & $\begin{array}{l}\text { Tribe: Benincaseae } \\
\text { Subtribe: } \\
\text { Benincasinae }\end{array}$ & $\begin{array}{l}\text { Tribe: Benincaseae } \\
\text { Subtribe: } \\
\text { Benincasinae }\end{array}$ & Tribe: Benincaseae & Group B \\
\hline 12 & $\begin{array}{l}\text { Lemurosicyos } \\
\text { variegata (Cogn.) } \\
\text { Keraudren }\end{array}$ & $\begin{array}{l}\text { Madagascar, Du Puy } \\
\text { et al., M891 (K) }\end{array}$ & - & $\begin{array}{l}\text { Tribe: Benincaseae } \\
\text { Subtribe: } \\
\text { Benincasinae }\end{array}$ & $\begin{array}{l}\text { Tribe: Benincaseae } \\
\text { Subtribe: } \\
\text { Benincasinae }\end{array}$ & Tribe: Benincaseae & Group B \\
\hline 13 & $\begin{array}{l}\text { Luffa acutangula } \\
\text { (L.) Roxb., }\end{array}$ & $\begin{array}{l}\text { Egypt, Cairo } \\
\text { gardens, Shabetai } \\
\text { Z6943 (CAIM) }\end{array}$ & $\begin{array}{l}\text { Tribe: Benincaseae } \\
\text { Subtribe: Luffinae }\end{array}$ & Tribe: Luffeae & Tribe: Luffeae & Tribe: Sicyoeae & Group D \\
\hline 14 & $\begin{array}{l}\text { Luffa cylindrica (L.) } \\
\text { Roem. }\end{array}$ & $\begin{array}{l}\text { Egypt, Sohag, abdel } \\
\text { Khalik s.n. (SHG) }\end{array}$ & $\begin{array}{l}\text { Tribe: Benincaseae } \\
\text { Subtribe: Luffinae }\end{array}$ & Tribe: Luffeae & Tribe: Luffeae & Tribe: Sicyoeae & Group D \\
\hline 15 & $\begin{array}{l}\text { Nothoalsomitra } \\
\text { suberosa }\end{array}$ & $\begin{array}{l}\text { Australia, } \\
\text { Queensland, Telford } \\
\text { et al., } 9007(\mathrm{~K}) \text {. }\end{array}$ & - & $\begin{array}{l}\text { Tribe: Benincaseae } \\
\text { Subtribe: } \\
\text { Benincasinae }\end{array}$ & $\begin{array}{l}\text { Tribe: Benincaseae } \\
\text { Subtribe: } \\
\text { Benincasinae }\end{array}$ & Tribe: Sicyoeae & Group E \\
\hline 16 & $\begin{array}{l}\text { Ruthalicia longipes } \\
\text { (Hook.f.) C.Jeffrey }\end{array}$ & $\begin{array}{l}\text { Nigeria, Onochie } \\
\text { FHI } 34320(\mathrm{~K}) .\end{array}$ & - & $\begin{array}{l}\text { Tribe: Benincaseae } \\
\text { Subtribe: } \\
\text { Benincasinae }\end{array}$ & $\begin{array}{l}\text { Tribe: Benincaseae } \\
\text { Subtribe: } \\
\text { Benincasinae }\end{array}$ & Tribe: Benincaseae & Group F \\
\hline
\end{tabular}


Table 2. Seed morphological characters of the studied taxa in the Cucurbitaceae.

\begin{tabular}{|c|c|c|c|c|c|c|c|c|}
\hline $\mathbf{N}$ & Taxon & Seed colour & Seed shape & Seed surface & $\begin{array}{l}\text { Seed size (long } \\
\text { x wide) } \mathrm{mm}\end{array}$ & $\begin{array}{c}\text { Outer of } \\
\text { epidermal cell } \\
\text { shape }\end{array}$ & $\begin{array}{l}\text { Anticlinal cell wall } \\
\text { boundaries }\end{array}$ & $\begin{array}{c}\text { Periclinal cell } \\
\text { wall }\end{array}$ \\
\hline 1 & $\begin{array}{l}\text { Acanthosicyos } \\
\text { horridus Welw. ex } \\
\text { Hook.f. }\end{array}$ & Cream & Ovoid & $\begin{array}{l}\text { Testa thick, hard, } \\
\text { wingless }\end{array}$ & $10-12 \times 6-7$ & $\begin{array}{l}\text { Isodiametric, } \\
\text { 5-6 gonal cells }\end{array}$ & $\begin{array}{l}\text { Straight, raised; } \\
\text { smooth to fine } \\
\text { folds }\end{array}$ & $\begin{array}{l}\text { Flat; micro- } \\
\text { papillate }\end{array}$ \\
\hline 2 & $\begin{array}{l}\text { Bambekea racemosa } \\
\text { Cogn. }\end{array}$ & $\begin{array}{l}\text { Yellowish } \\
\text { brown }\end{array}$ & Ovoid & $\begin{array}{l}\text { Smooth, wingless, } \\
\text { arillate }\end{array}$ & $5-6 \times 3-4$ & $\begin{array}{l}\text { Irregular, } \\
\text { polygonal cells }\end{array}$ & $\begin{array}{l}\text { Straight to slightly } \\
\text { sinuous, slightly } \\
\text { raised; folded }\end{array}$ & $\begin{array}{l}\text { Flat to concave; } \\
\text { smooth to fine } \\
\text { folds }\end{array}$ \\
\hline 3 & $\begin{array}{l}\text { Benincasa hispida } \\
\text { (Thumb.) Cogn. }\end{array}$ & $\begin{array}{l}\text { Yellowish } \\
\text { brown }\end{array}$ & Oblong & $\begin{array}{l}\text { Flat, smooth, } \\
\text { with narrow ridge } \\
\text { (wing) }\end{array}$ & $10-15 \times 5-8$ & $\begin{array}{l}\text { Elongate in one } \\
\text { direction }\end{array}$ & $\begin{array}{l}\text { Straight, raised; } \\
\text { smooth to fine } \\
\text { folds }\end{array}$ & $\begin{array}{l}\text { Flat; smooth to } \\
\text { fine folds }\end{array}$ \\
\hline 4 & Bryonia alba $\mathrm{L}$. & Brown & Ovoid & $\begin{array}{l}\text { Flat, smooth, } \\
\text { with narrow ridge } \\
\text { (wing) }\end{array}$ & $3.6-4 \times 2.7-3$ & $\begin{array}{l}\text { Irregular, } \\
\text { polygonal cells }\end{array}$ & $\begin{array}{l}\text { Straight to slightly } \\
\text { sinuous, raised; } \\
\text { folded }\end{array}$ & $\begin{array}{l}\text { Concave; } \\
\text { smooth to fine } \\
\text { folds }\end{array}$ \\
\hline 5 & Bryonia cretica L. & $\begin{array}{l}\text { Orange- } \\
\text { brown }\end{array}$ & Ovoid & $\begin{array}{l}\text { Flat, smooth with } \\
\text { narrow ridge } \\
\text { (wing) }\end{array}$ & $5-6 \times 4-6$ & $\begin{array}{l}\text { Irregular, } \\
\text { polygonal cells }\end{array}$ & $\begin{array}{l}\text { Undulate, raised; } \\
\text { smooth to fine } \\
\text { folds }\end{array}$ & $\begin{array}{l}\text { Flat to concave; } \\
\text { smooth }\end{array}$ \\
\hline 6 & Bryonia dioica Jacq & Light brown & Obovoid & $\begin{array}{l}\text { Flat, smooth with } \\
\text { narrow ridge } \\
\text { (wing) }\end{array}$ & $3.8-4.2 \times 3.2-3.4$ & $\begin{array}{l}\text { Isodiametric, } \\
5-6 \text { gonal cells }\end{array}$ & $\begin{array}{l}\text { Straight to slightly } \\
\text { sinuous, raised; } \\
\text { smooth to fine } \\
\text { folds }\end{array}$ & $\begin{array}{l}\text { Flat; smooth to } \\
\text { fine folds }\end{array}$ \\
\hline 7 & $\begin{array}{l}\text { Citrullus colocynthis } \\
\text { (L.) Schrad. }\end{array}$ & $\begin{array}{l}\text { Yellowish } \\
\text { brown }\end{array}$ & $\begin{array}{l}\text { Oblong- } \\
\text { obovoid }\end{array}$ & $\begin{array}{l}\text { Flat, smooth, } \\
\text { wingless }\end{array}$ & $6.2-10 \times 3.6-5$ & $\begin{array}{l}\text { Irregular, } \\
\text { polygonal cells }\end{array}$ & $\begin{array}{l}\text { Undulate, raised; } \\
\text { smooth to fine } \\
\text { folds }\end{array}$ & $\begin{array}{l}\text { Flat; smooth to } \\
\text { fine folds }\end{array}$ \\
\hline 8 & $\begin{array}{l}\text { Citrullus ecirrhosus } \\
\text { Cong. }\end{array}$ & $\begin{array}{l}\text { Black to } \\
\text { brown }\end{array}$ & Obovoid & $\begin{array}{l}\text { Flat, smooth, } \\
\text { wingless, arillate }\end{array}$ & $6.2-9 \times 4-6$ & $\begin{array}{l}\text { Irregular, } \\
\text { polygonal cells }\end{array}$ & $\begin{array}{l}\text { Undulate, raised; } \\
\text { smooth to fine } \\
\text { folds }\end{array}$ & $\begin{array}{l}\text { Flat; micro- } \\
\text { papillate }\end{array}$ \\
\hline 9 & $\begin{array}{l}\text { Citrullus lanatus } \\
\text { (Thunb.) Matsum. \& } \\
\text { Nakai }\end{array}$ & $\begin{array}{l}\text { Black to } \\
\text { brown }\end{array}$ & $\begin{array}{l}\text { Obovoid- } \\
\text { oblong }\end{array}$ & $\begin{array}{l}\text { Flat, smooth with } \\
\text { narrow ridge } \\
\text { (wing), arillate }\end{array}$ & $7-10 \times 5-7$ & $\begin{array}{l}5-6 \text { gonal cells } \\
\text { to elongate in } \\
\text { one direction }\end{array}$ & $\begin{array}{l}\text { Straight, raised; } \\
\text { smooth to fine } \\
\text { folds }\end{array}$ & $\begin{array}{l}\text { Flat; micro- } \\
\text { papillate }\end{array}$ \\
\hline 10 & $\begin{array}{l}\text { Diplocyclos palmatus } \\
\text { (L.) C.Jeffrey }\end{array}$ & Brown & Pyriform & $\begin{array}{l}\text { Slightly } \\
\text { scorbiculate } \\
\text { at the middle, } \\
\text { strongly winged, } \\
\text { arillate }\end{array}$ & $5-6 \times 4-4.8$ & $\begin{array}{l}5-6 \text { gonal cells } \\
\text { to elongate in } \\
\text { one direction }\end{array}$ & $\begin{array}{l}\text { Straight, raised; } \\
\text { smooth to fine } \\
\text { folds }\end{array}$ & $\begin{array}{l}\text { Flat; smooth to } \\
\text { fine folds }\end{array}$ \\
\hline 11 & $\begin{array}{l}\text { Lagenaria sphaerica } \\
\text { (Sond.) Naud }\end{array}$ & $\begin{array}{l}\text { whitish- } \\
\text { yellow }\end{array}$ & $\begin{array}{l}\text { Oblong- } \\
\text { obovoid }\end{array}$ & $\begin{array}{l}\text { Flat, compressed, } \\
\text { pointed at one } \\
\text { end, smooth, } \\
\text { with narrow ridge } \\
\text { (wing), arillate }\end{array}$ & $6-7 \times 4-5$ & $\begin{array}{l}\text { Isodiametric, } \\
5-6 \text { gonal cells }\end{array}$ & $\begin{array}{l}\text { Straight, raised; } \\
\text { smooth to fine } \\
\text { folds }\end{array}$ & $\begin{array}{l}\text { Flat to slightly } \\
\text { convex; smooth } \\
\text { to fine folds }\end{array}$ \\
\hline 12 & $\begin{array}{l}\text { Lemurosicyos } \\
\text { variegata (Cogn.) } \\
\text { Keraudren }\end{array}$ & $\begin{array}{l}\text { Yellowish } \\
\text { brown }\end{array}$ & Oblong & $\begin{array}{l}\text { Flat, test hard } \\
\text { and with dentate } \\
\text { margin, arillate }\end{array}$ & $9-10 \times 5-5.8$ & $\begin{array}{l}\text { Irregular, } \\
\text { polygonal cells }\end{array}$ & $\begin{array}{l}\text { Straight to slightly } \\
\text { sinuous, slightly } \\
\text { raised; smooth to } \\
\text { fine folds }\end{array}$ & $\begin{array}{l}\text { Flat to slightly } \\
\text { convex; folded }\end{array}$ \\
\hline 13 & $\begin{array}{l}\text { Luffa acutangula (L.) } \\
\text { Roxb., }\end{array}$ & Black & $\begin{array}{l}\text { Oblong- } \\
\text { obovoid }\end{array}$ & $\begin{array}{l}\text { Flat, compressed, } \\
\text { rugose, wingless }\end{array}$ & $11-13 \times 7-8$ & $\begin{array}{l}\text { Irregular, } \\
\text { polygonal cells }\end{array}$ & $\begin{array}{l}\text { Undulate, raised; } \\
\text { folded }\end{array}$ & $\begin{array}{l}\text { Flat; smooth to } \\
\text { fine folds }\end{array}$ \\
\hline 14 & $\begin{array}{l}\text { Luffa cylindrica (L.) } \\
\text { Roem. }\end{array}$ & Black & Ovoid & $\begin{array}{l}\text { Flat, compressed, } \\
\text { smooth, with } \\
\text { narrow ridge } \\
\text { (wing) }\end{array}$ & $10-14 \times 7-10$ & $\begin{array}{l}\text { Irregular, } \\
\text { polygonal cells }\end{array}$ & $\begin{array}{l}\text { Undulate, raised; } \\
\text { folded }\end{array}$ & Flat; folded \\
\hline 15 & $\begin{array}{l}\text { Nothoalsomitra } \\
\text { suberosa (F.M.Bailey) } \\
\text { Telford }\end{array}$ & Brown & Ovoid & $\begin{array}{l}\text { Flat, smooth, } \\
\text { wingless }\end{array}$ & $11-13 \times 7-9$ & $\begin{array}{l}\text { Irregular, } \\
\text { polygonal cells }\end{array}$ & $\begin{array}{l}\text { Straight to slightly } \\
\text { sinuous, raised; } \\
\text { smooth to fine } \\
\text { folds }\end{array}$ & $\begin{array}{l}\text { Flat to concave; } \\
\text { smooth }\end{array}$ \\
\hline 16 & $\begin{array}{l}\text { Ruthalicia longipes } \\
\text { (Hook.f.) C.Jeffrey }\end{array}$ & $\begin{array}{l}\text { Yellowish } \\
\text { brown }\end{array}$ & Oblong & $\begin{array}{l}\text { Flat, compressed, } \\
\text { slightly } \\
\text { sculptured, with } \\
\text { narrow wing }\end{array}$ & $10-12 \times 5-6$ & $\begin{array}{l}\text { Elongate in one } \\
\text { direction }\end{array}$ & $\begin{array}{l}\text { Straight to slightly } \\
\text { sinuous, raised; } \\
\text { folded }\end{array}$ & Flat, striate \\
\hline
\end{tabular}


Citrullus ecirrhosus and C. lanatus; brown in Bryonia alba, Diplocyclos palmatus, and Nothoalsomitra suberosa; whitishyellow in Acanthosicyos horridus and Lagenaria spaerica; and yellow to brown in the rest of the species.

\subsection{Seed shape}

Seed shape in the tribe Benincasinae can be categorized as follows: pear shaped in Diplocyclos palmatus (Fig. 3C); obovoid in Bryonia dioica (Fig. 2C); oblong in Benincasa hispida, Lemurosicyos variegata, and Ruthalicia longipes (Figs. 1E, 3G, and 4G); oblong-obovoid in Citrullus colocynthis, C. lanatus, Lagenaria spaerica, and Luffa acutangula (Figs. 2E, $3 \mathrm{~A}$ and E, and 4A); and ovoid in Acanthosicyos horridus, Bambekea racemosa, Bryonia alba, Bryonia cretica, Luffa cylindrica, and Nothoalsomitra suberosa (Figs. 1A, C, and G; $2 \mathrm{~A}$; and $4 \mathrm{C}$ and $\mathrm{E}$ ).

\subsection{Seed surface}

The seed sculpture of the studied taxa showed great variation. They varied tremendously from scrobiculate (pitted; i.e., a surface covered with hollows) in Diplocyclos palmatus (Fig. 3D); rugose in Luffa acutangula (Fig. 4B); thick (slightly sculptured) in Acanthosicyos horridus, Lemurosicyos variegata, and Ruthalicia longipes (Figs. 1B, $3 \mathrm{H}$, and $4 \mathrm{H}$ ); and smooth in the rest of the taxa (Figs. 1C, E, and G; 2A, C, E, and G; and 3A).

\subsection{Seed ridge}

Seed ridges showed great variation among the studied taxa. They included seeds with the following characters: strong ridges in Diplocyclos palmatus (Fig. 3C); dentate margins or ridges in Lemurosicyos variegata (Fig. 3G); no ridges in Acanthosicyos horridus, Bambekea racemosa, Citrullus colocynthis, C. ecirrhosus, Luffa acutangula, and Nothoalsomitra suberosa (Figs. 1A and C, 2E and G, and 4A and $\mathrm{E}$ ); and narrow ridges in the rest of the species (Figs. $1 \mathrm{E}$ and $\mathrm{G}, 2 \mathrm{~A}$ and $\mathrm{C}, 3 \mathrm{~A}$, and $4 \mathrm{C}$ and $\mathrm{G}$ ).

\subsection{Seed arillate}

The outer integument covering a seed after fertilization is called an arilloid jacket. The arilloid jacket is present in Bambekea racemosa, Citrullus ecirrhosus, C. lanatus, Diplocyclos palmatus, Lagenaria spaerica, and Lemurosicyos variegata (Figs. 1C; 2G; 3A, C, E, and G), or absent in the rest of the taxa (1A, E, and G; 2A, C, and E; 3G; 4A, C, E, and G).

\subsection{Seed size}

Seed dimensions varied significantly among the examined taxa. The biggest seeds (10-15 $\mathrm{mm} \times 5-8 \mathrm{~mm}$ ) were measured in Acanthosicyos horridus, Benincasa hispida, Luffa acutangula,
L.cylindrical, Nothoalsomitra suberosa, and Ruthalicia longipes; the smallest seeds $(3.6-4 \mathrm{~mm} \times 2.7-3.4 \mathrm{~mm})$ were measured in Bryonia alba and Bryonia dioica. The rest of the species had slightly bigger seeds $(5-10 \mathrm{~mm} \times 4-5.5 \mathrm{~mm})$ (Table 2$)$.

\subsection{Shape of outer epidermal cells}

Outer epidermal cells can be of considerable diagnostic value for systematics. The outer epidermal cells varied from elongate in Benincasa hispida and Ruthalicia longipes (Figs. 1F and 4H), isodiametric to 5-6 gonal in Acanthosicyos horridus, Bryonia dioica, and Lagenaria spaerica (Figs. 1B, 2D, and 3F), 5-6 gonal to elongate in Citrullus lanatus and Diplocyclos palmatus (Figs. 3B and D), and irregular to polygonal in the rest of the taxa (Figs. 1D and H; 2B, F, and H; 3H; 4B, D, and F).

\subsection{Anticlinal cell wall boundaries}

Anticlinal cell wall boundaries are mostly well developed. There are three types of anticlinal cell wall boundaries: the first type is undulate in Bryonia cretica, Citrillus ecirrhosus, Luffa acutangula, and L. cylindrical (Figs. 2B; 4B, D, and $\mathrm{H}$ ); the second type is straight in Acanthosicyos horridus, Benincasa hispida, Citrullus lanatus, Diplocyclos palmatus, and Lagenaria spaerica (Figs. 1B and D; 3B, D, and F); the third type is straight to slightly sinuous in the rest of the taxa (Figs. 1D and $\mathrm{H}, 2 \mathrm{D}$ and $\mathrm{F}, 3 \mathrm{H}$, and $4 \mathrm{~F}$ and $\mathrm{H}$ ). Based on the relief of these cell wall boundaries there are two types of boundaries: slightly raised in Bambekea racemosa (Fig. 1D) and raised in the rest of the taxa (Figs. 1-4, except 1D).

\subsection{Periclinal cell wall}

The curvature of the outer periclinal cell wall can be a good diagnostic character. There are four different shapes for this cell wall: flat to convex in Lagenaria spaerica and Lemurosicyos variegata (Figs. $3 \mathrm{~F}$ and $\mathrm{H}$ ); flat to concave in Bambekea racemosa, Bryonia cretica, and Nothoalsomitra suberosa (Figs. 1D, 2B, and 4F); concave in Bryonia alba (Fig. 1H); flat in the rest of the taxa (Figs. 1B and E; 2D, F, and $\mathrm{H} ; 3 \mathrm{~B}$ and $\mathrm{D} ; 4 \mathrm{~B}, \mathrm{D}$, and $\mathrm{H}$ ). The sculpture of the outer cell wall greatly varied among the studied taxa. There were five different shapes for the surface of the outer cell wall: smooth in Bryonia cretica and Nothoalsomitra suberosa (Figs. 2B and 4F); folded in Lemurosicyos variegata and Luffa cylindrical (Figs. 4B and D); striate in Ruthalicia longipes (Fig. 4H); micro-papillate in Acanthosicyos horridus, Citrullus ecirrhosus, and C. lanatus (Figs. 1B, 2H, and 3B); and smooth to fine folds in the rest of the taxa.

\subsection{Cluster and Principal coordinates analysis (PCO)}

The results for the cluster and principal coordinates analyses are presented in Figs. 5-8. In the UPGMA dendrogram and PCO plots (first three principal coordinates axes 

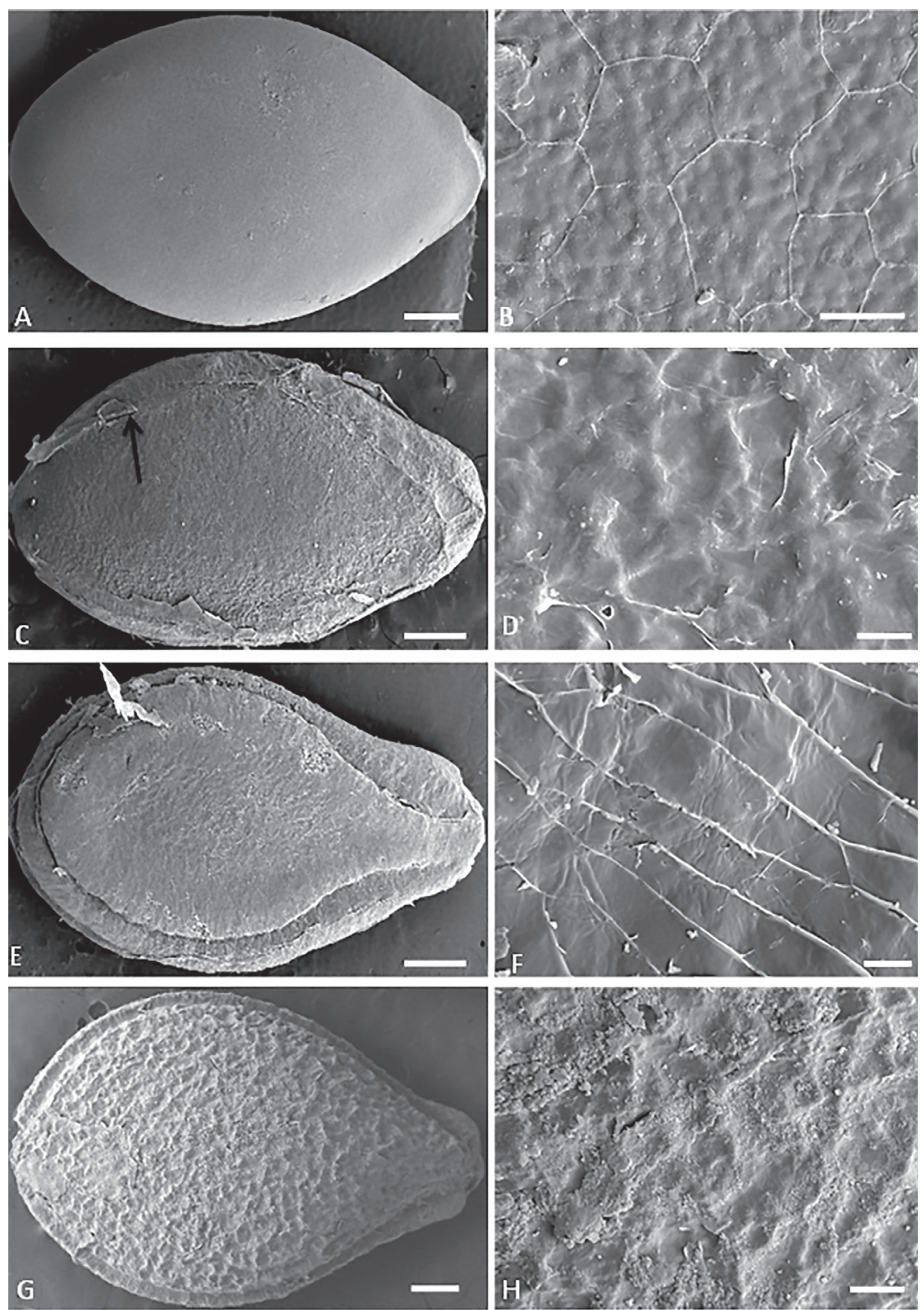

Figure 1. SEM photographs of seeds. A and B Acanthosicyos horridus. C and D Bambekea racemosa. E and F Benincasa hispida. G and H Bryonia alba. A, C, E, and G entire seed; B, D, F, and H enlargement of seed coat. Scale bars: $500 \mu \mathrm{m}$ in A, C, E and G; $50 \mu \mathrm{m}$ in B; $20 \mu \mathrm{m}$ in D; $25 \mu \mathrm{m}$ in F and H. The arrow refers to the arilloid jacket.

was $56.8 \%$ of the total observed variation. Plots $1 / 2,1 / 3$, and $2 / 3$ together show six groups (Figs. 6-8). The main characters explained the separation between groups (characters with high factor loading were $>0.6$ ). Six major branches and groups (A-F) with approximately $44 \%$ similarity were distinguished. 1) Branch A included only Bambekea racemosa (tribe Coniandreae). This branch showed the largest distance from all other branches. 2) Group B included Lagenaria spaerica and Lemurosicyos variegate (tribe Benincaseae). 3) Group C contained Citrullus ecirrhosus, C. lanatus, and Diplocyclos palmatus (tribe Benincaseae). 4) Group D comprised Luffa acutangula and L. cylindrica (tribe Luffeae). 

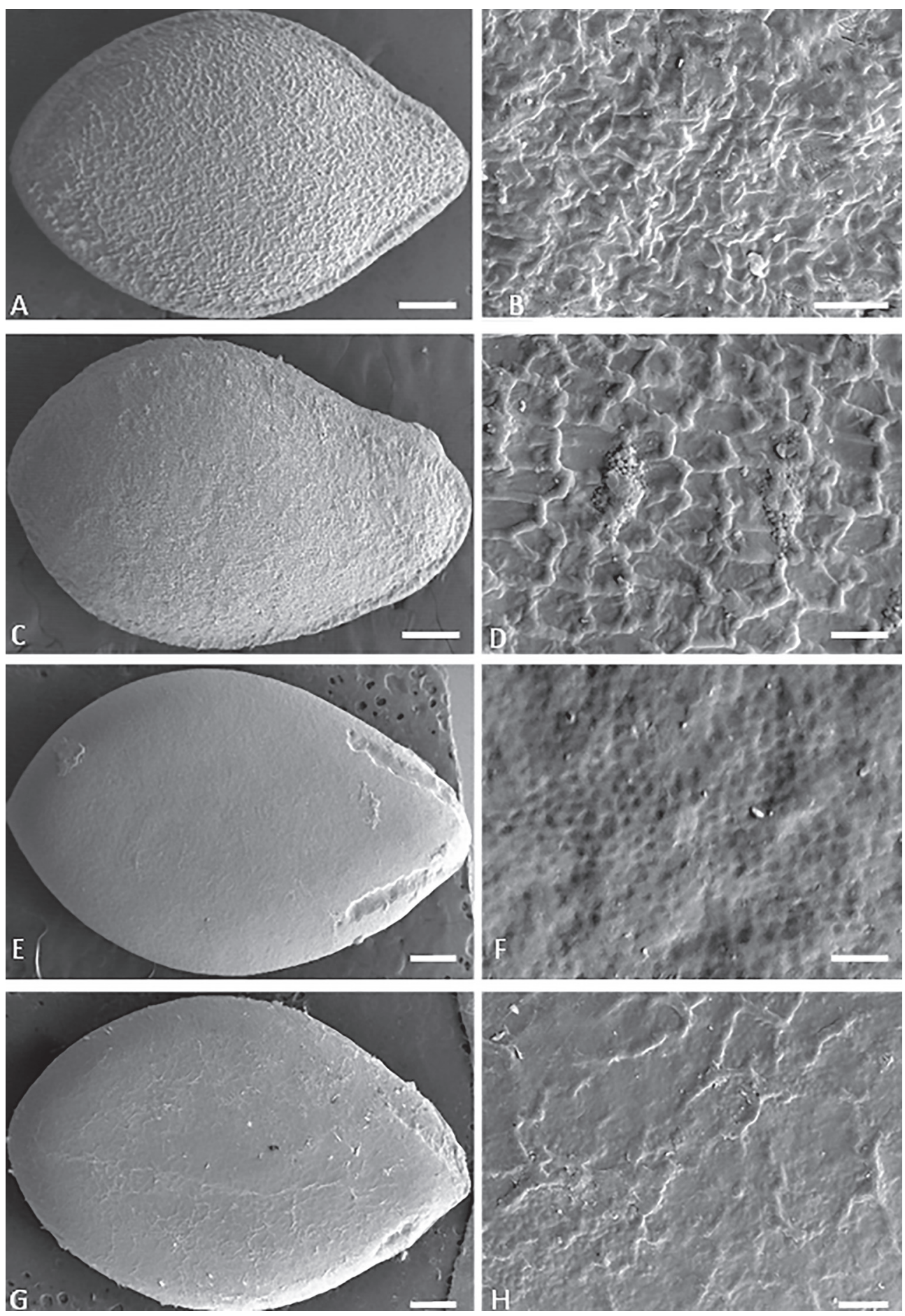

Figure 2. SEM photographs of seeds. A and B Bryonia cretica. C and D Bryonia dioica. E and F Citrullus colocynthis. G and H Citrullus ecirrhosus. A, C, E, and G entire seed; B, D, F, and H enlargement of seed coat. Scale bars: $500 \mu \mathrm{m}$ in A, C, E, and G; $100 \mu \mathrm{m}$ in B and H; $50 \mu \mathrm{m}$ in D and F.

5) Group E was divided into two subgroups: a subgroup with Bryonia dioica and Citrullus colocynthis (tribe Benincaseae), and a subgroup with Bryonia alba, Bryonia cretica (tribe Benincaseae) and Nothoalsomitra suberosa (tribe Luffeae). 6) Group F included Acanthosicyos horridus, Benincasa hispida, and Ruthalicia longipes (tribe Benincaseae).
Some genera and tribes showed intra variability among themselves. In general, UPGMA and PCO indicated that seed morphology followed the currently applied tribal classification of Cucurbitaceae by Jeffrey (2005), AchiganDako (2008), and Schaefer \& Renner (2011). 
Key to the identification of some tribes of Cucurbitaceae based on seed characters

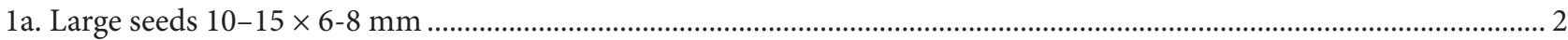

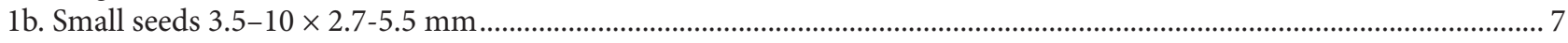

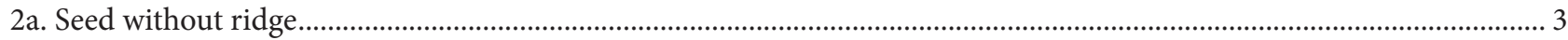

2b. Seed with narrow ridge......................................................................................................................................... 5

3a. Seed whitish-yellow; thick; sculpture of periclinal wall micro-papillate ..........................................Acanthosicyos horridus

3b. Seed black to brown; smooth or rugose; sculpture of periclinal wall smooth to fine folds .......................................... 4

4a. Seed black; oblong-obovoid; rugose; anticlinal boundaries, undulate..................................................... Luffa acutangula

4b. Seed brown; ovoid; smooth; anticlinal boundaries, straight to slightly sinuous.......................... Nothoalsomitra suberosa

5a. Seed black; ovoid; epidermal cell irregular to polygonal cells................................................................... Luffa cylindrica

5b. Seed yellowish brown; oblong; epidermal cell elongate in one direction .......................................................................... 6

6a. Seed thick; sculpture of periclinal wall striate ..................................................................................... Ruthalicia longipes

6b. Seed smooth; sculpture of periclinal wall smooth to fine folds ................................................................Benincasa hispida

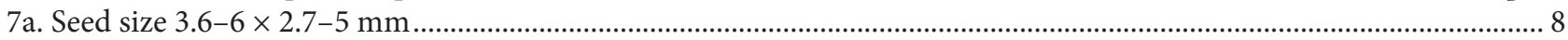

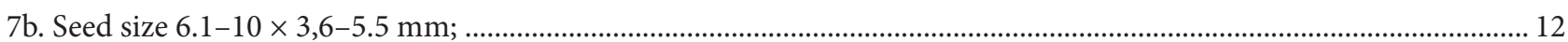

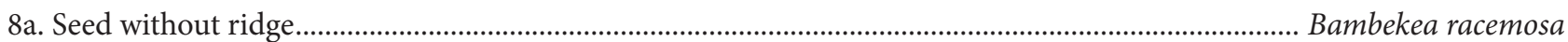

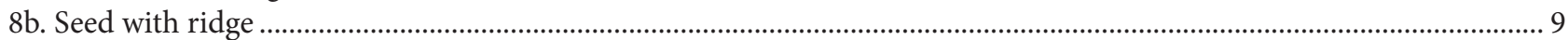

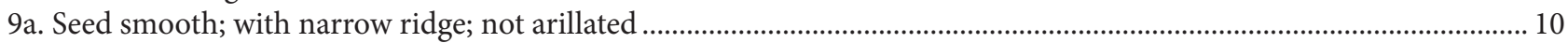

9b. Seed scorbiculate; strongly ridge; arillated .......................................................................................... Diplocyclos palmatus

10a. Seed size 3.6-4.2 $\times 2.7-3.4 \mathrm{~mm}$; brown to light brown; anticlinal boundaries straight to slightly sinuous ................. 11

10b. Seed size 5-6 × 4-6 mm; orange-brown; anticlinal boundaries undulate.............................................. Bryonia cretica

11a. Seed ovoid; brown; epidermal cell irregular to polygonal cells; periclinal cell wall concave ....................... Bryonia alba

11b. Seed obovoid; light brown; epidermal cell isodiametric, 5-6 gonal cells; periclinal cell wall flat ............. Bryonia dioica

12a. Seed without ridge; anticlinal boundaries undulate ……….................................................................................... 13

12b. Seed with ridge; anticlinal boundaries straight to slightly sinuous .............................................................................. 14

13a. Seed black to brown; arillated; sculpture of periclinal wall micro-papillate ....................................... Citrullus ecirrhosus

13b. Seed yellow brown; not arillated; sculpture of periclinal wall smooth to fine folds......................... Citrullus colocynthis

14a. Seed oblong; thick; with dentate margin; epidermal cell irreguklar, polygonal cells ......................emurosicyos variegata

14b. Seed oblong-obovoid; smooth; with narrow ridge epidermal cell isodiametric, 5-6 gonal cells to elongate in one direction

Citrullus lanatus

15a. Seed black to brown; periclinal cell wall flat; micro-papillate.

Lagenaria sphaerica

\section{Discussion}

Several authors have tried to provide an acceptable system to classify the family Cucurbitaceae into subfamilies, tribes, and subtribes (Hooker 1867; Jeffrey 1980; 1990; Wilde \& Duyfjes 2006 a; b; c; Kocyan et al. 2007; Schaefer \& Renner 2011). These studies were based on morphological characters, such as life forms, leaves, flowers, fruits, seeds, and pollen grains. In the present study, we used a number of seed characters based on details of the seed coat surface. UPGMA provided an insight into the degree of similarity among the species and showed whether they formed groups or clusters, indicating the range of variation within and among tribes. PCO indicated which characters were important on the axes, which were the most significant based on the highest factor loading (Table 3), and hence clarified which characters caused the separation between groups and were useful to distinguish taxa. Generally, our results confirmed congruence between the UPGMA clustering and PCO analyses, and suggested six groups. In general, the results showed that different patterns of seed morphology were helpful in distinguishing various species and to confirm the tribe and subtribe classifications as proposed by Schaefer \& Renner (2011), Jeffrey (2005), and Achigan-Dako (2008).

\subsection{Tribes classification}

\subsubsection{Tribe Coniandreae Endl. ex M. Roem (1846) (groups A)}

According to the cluster and PCO analysis, Bambekea racemosa (tribe Coniandreae) showed the largest distance from all other groups, and was distinct from the others by having wingless seed; yellowish brown; straight to slightly sinuous, slightly raised, anticlinal cell wall boundaries; and by seed size. Bambekea racemosa corresponded to the previously recognized position within tribe Benincaseae subtribe Benincasinae (Jeffrey 2005; Achigan-Dako 2008). However, Schaefer \& Renner (2011) treated this species as sited in tribe Coniandreae based on 14 DNA regions from the three plant genomes: the mitochondrial nad $1 \mathrm{~b} / \mathrm{c}$ intron 

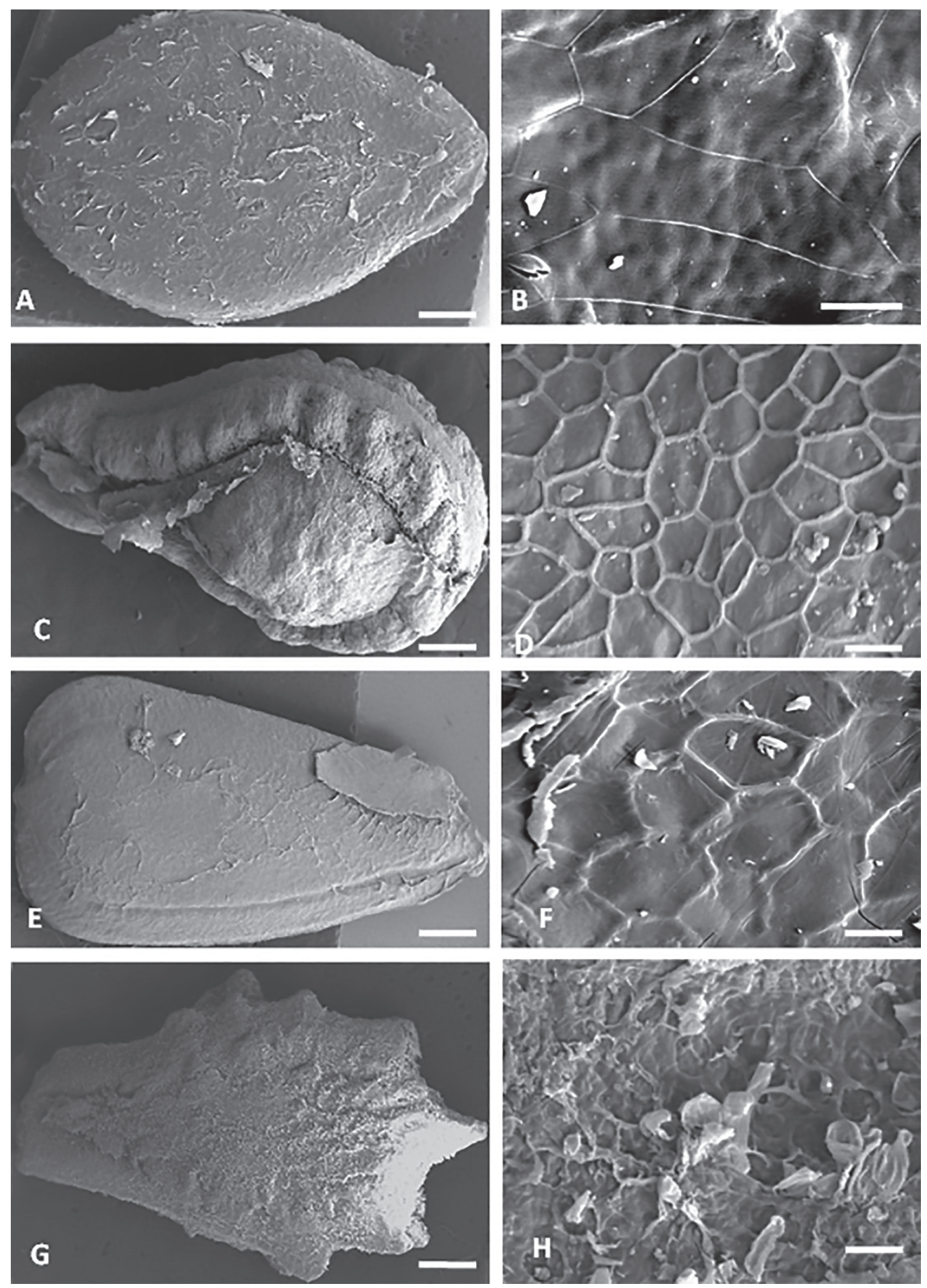

Figure 3. SEM photographs of seeds. A and B Citrullus lanatus. C and D Diplocyclos palmatus. E and F Lagenaria sphaerica. G and H Lemurosicyos variegata. A, C, E, and G entire seed; B, D, F, and H enlargement of seed coat. Scale bars: $500 \mu \mathrm{m}$ in A, C, E, and G; $50 \mu \mathrm{m}$ in B and D; $25 \mu \mathrm{m}$ in F; and $43 \mu \mathrm{m}$ in H.

and $m a t R$ gene; the nuclear ribosomal 18S, ITS1-5.8S-ITS2, and $28 \mathrm{~S}$ genes; and the plastid genes $r b c L$, matK, $n d h F, a t p B$, $\operatorname{trnL}, \operatorname{trnL}-\operatorname{trn} F, \operatorname{rpl20}-\mathrm{rps} 12, \operatorname{trnS}-\operatorname{trn} G$ and $\operatorname{trnH}-\mathrm{psbA}$, spacers, and introns.

Seed coat characters were used by Jeffrey (2005) to recircumscribe Coniandreae to include 19 genera, which was strongly supported by molecular data. Coniandreae seeds lack a hypodermis, while other Cucurbitaceae have seed coats with a hypodermis including one or many layers of sclerotic cells (Singh \& Dathan 2001). Based on results by Kocyan et al. (2007), Bambekea, Cucumeropsis, and Eureiandra may be sister to the Coniandreae (but this only has 

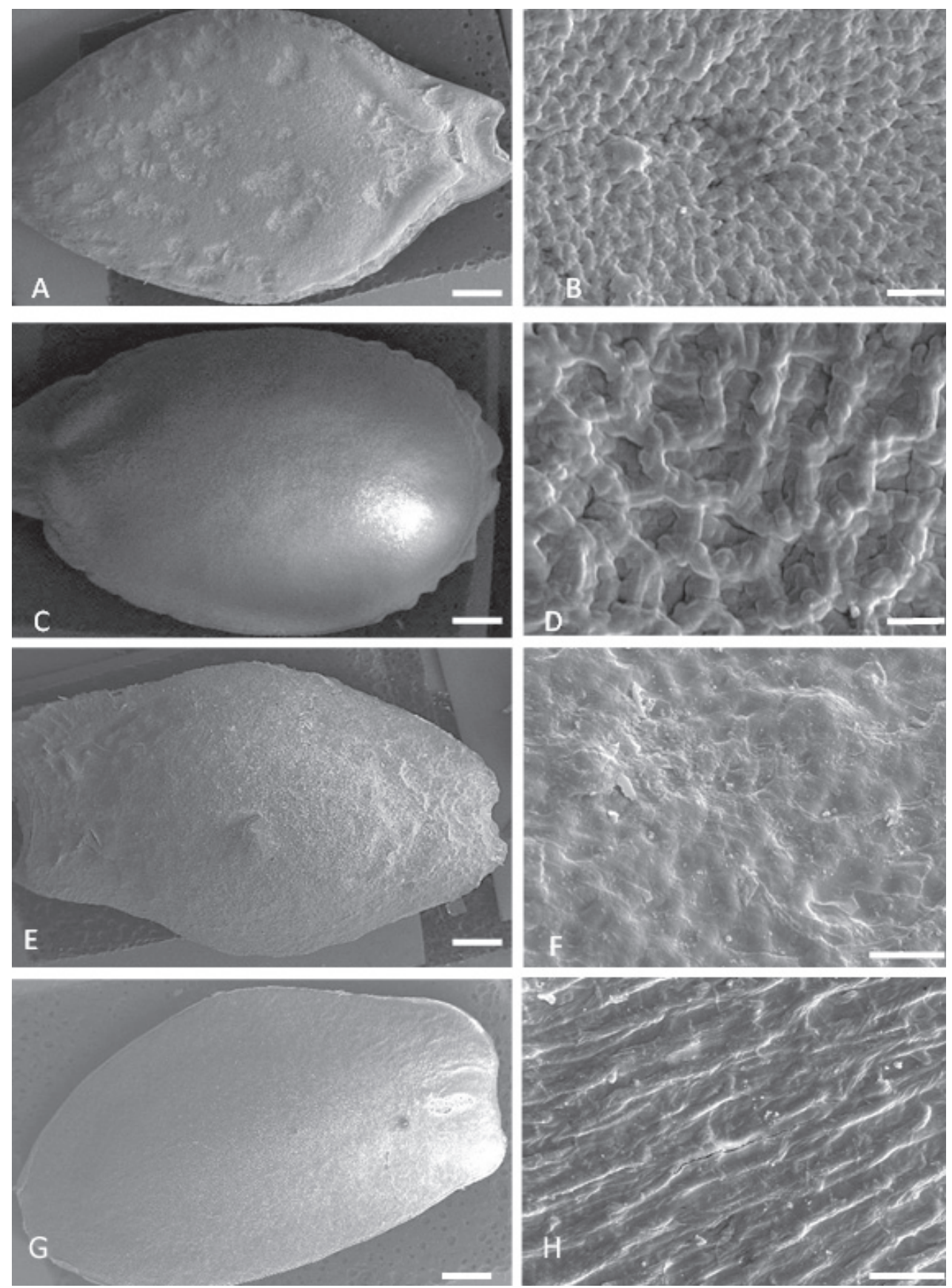

Figure 4. SEM photographs of seeds. A and B Luffa acutangula. C and D Luffa cylindrica. E and F Nothoalsomitra suberosa. G and H Ruthalicia longipes. A, C, E, and G entire seed; B, D, F, and H enlargement of seed coat. Scale bars: $500 \mu \mathrm{m}$ in A, C, E, and G; $50 \mu \mathrm{m}$ in B; $17 \mu \mathrm{m}$ in D; $100 \mu \mathrm{m}$ in F and H.

$68 \%$ bootstrap support) and probably should be included in that tribe; although Jeffrey (2005) still placed them in Benincaseae. This result agrees with those of Kocyan et al. (2007) and Schaefer \& Renner (2011) who separated it as a tribe.

\subsubsection{Tribe Benincaseae Ser. (1825) (groups B, C, and F)}

Walters \& Decker-Walters (1991) examined eight species belonging to the tribe Benincaseae using starch gel electrophoresis and showed three major evolutionary line- ages within the Benincaseae: 1) Benincasa, Citrullus, and Lagenaria, 2) Bryonia and Ecballium, and 3) Luffa. Chung et al. (2003) investigated the genetic relationships in Benincaseae, Cucurbiteae, Joliffieae, Melothrieae, and Sicyeae tribes of Cucurbitaceae based on consensus chloroplast simple sequence repeats (ccSSR) and established previous biochemical and morphological data that indicated distinct lineages within the tribe Benincaseae and cast doubt on the hypothesis that Benincaseae was a monophyletic tribe. Kocyan et al. (2007) presented a phylogenetic network and 
Table 3. Seed morphological characters showing highest factor loading on the first three principal coordinates axes. The shaded numbers indicate characters with a high factor loading $>0.6$.

\begin{tabular}{|c|c|c|c|c|}
\hline \multirow{3}{*}{$\mathbf{N}$} & \multirow{3}{*}{ Characters } & \multicolumn{3}{|c|}{ Principal coordinates } \\
\hline & & 1 & 2 & 3 \\
\hline & & \multicolumn{3}{|c|}{ Factors loading } \\
\hline 1 & Seed shape & 0.73 & 0.52 & -0.47 \\
\hline 2 & Seed sculpture & 0.37 & -0.50 & 0.20 \\
\hline 3 & Seed wings & 0.31 & -0.65 & 0.12 \\
\hline 4 & Arillate (An exterior covering seed after fertilization) & -0.47 & 0.54 & 0.29 \\
\hline 5 & Seed color & 0.86 & 0.53 & -0.35 \\
\hline 6 & Seed size $(\mathrm{mm})$ (Length $\mathrm{x}$ width) & 0.43 & 0.92 & -0.61 \\
\hline 7 & Epidermal cell patterns & 0.55 & 0.11 & -0.32 \\
\hline 8 & Anticlinal walls & -0.52 & -0.39 & 0.49 \\
\hline 9 & Relief of cell wall boundaries & -0.23 & 0.47 & 0.71 \\
\hline 10 & Sculpture of anticlinal boundaries & 0.44 & -0.58 & 0.66 \\
\hline 11 & Curvature of outer periclinal cell wall & 0.20 & -0.76 & 0.29 \\
\hline 12 & Secondary cell wall sculpture & 0.54 & 0.11 & -0.27 \\
\hline \multicolumn{2}{|r|}{ Percentage per PCO } & 25.9 & 17.5 & 13.4 \\
\hline Perce & tage total variation for the first three principal coordinates amount $56.8 \%$ & & & \\
\hline
\end{tabular}

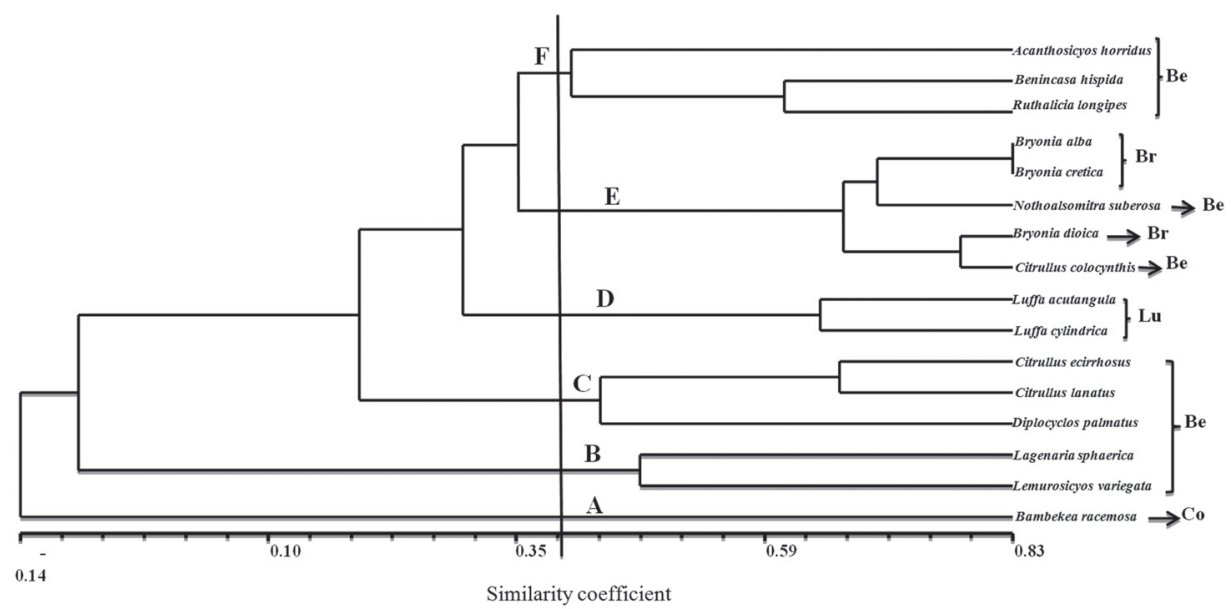

Figure 5. Dendrogram illustrating the relationships among the investigated species based on seed characters: $\mathbf{B e}$, tribe Benincaseae; $\mathbf{B r}$, tribe Bryonieae; $\mathbf{C o}$, tribe Coniandreae; Lu, tribe Luffeae.

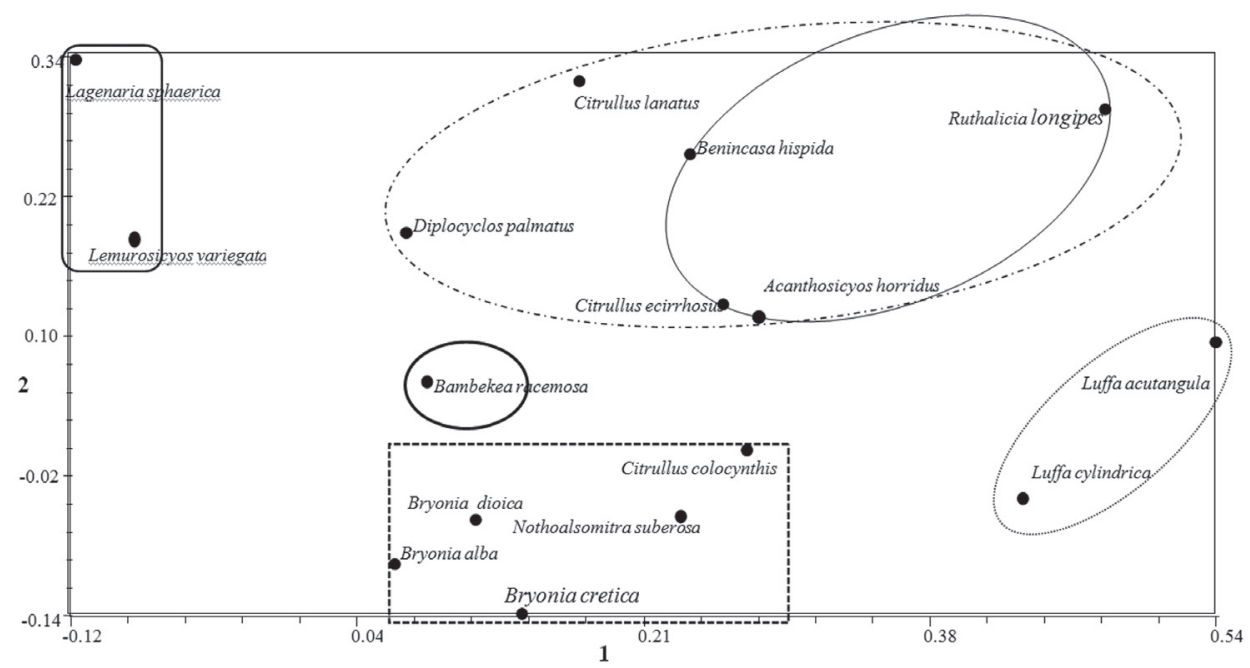

Figure 6. Scatterplot of the 16 OUTs plotted against the first principal coordinate by the second principal coordinate. 


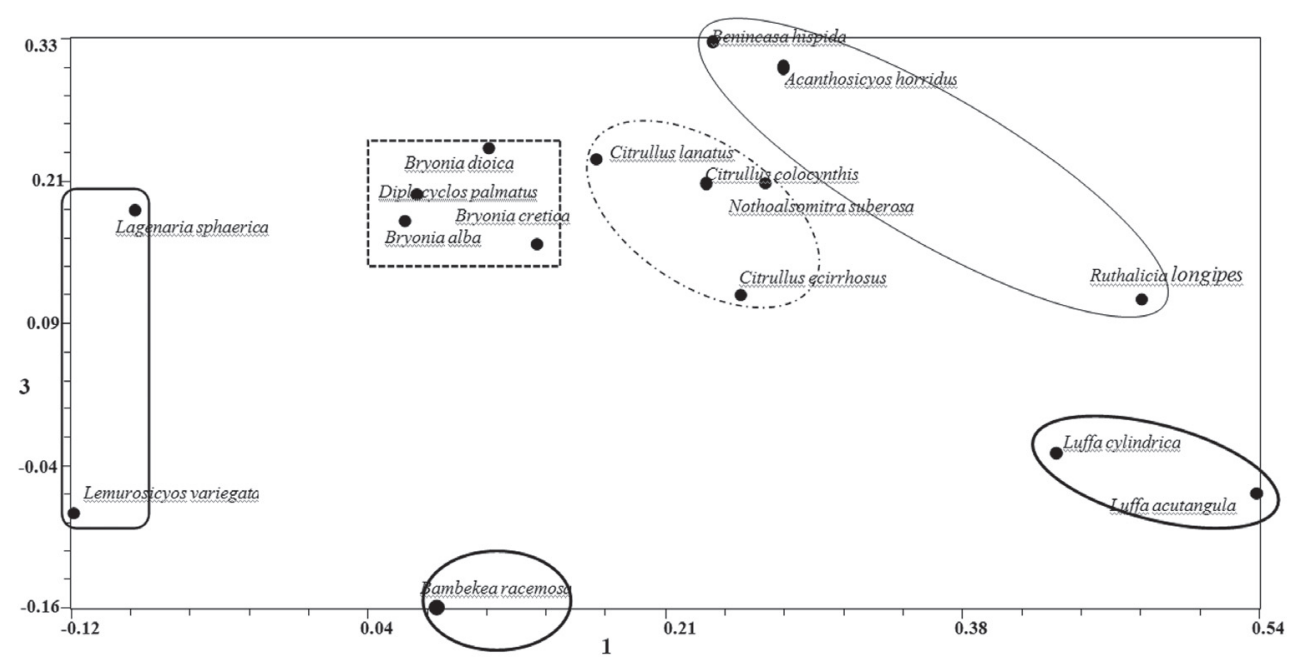

Figure 7. Scatterplot of the 16 OUTs plotted against the first principal coordinate by the third principal coordinate.

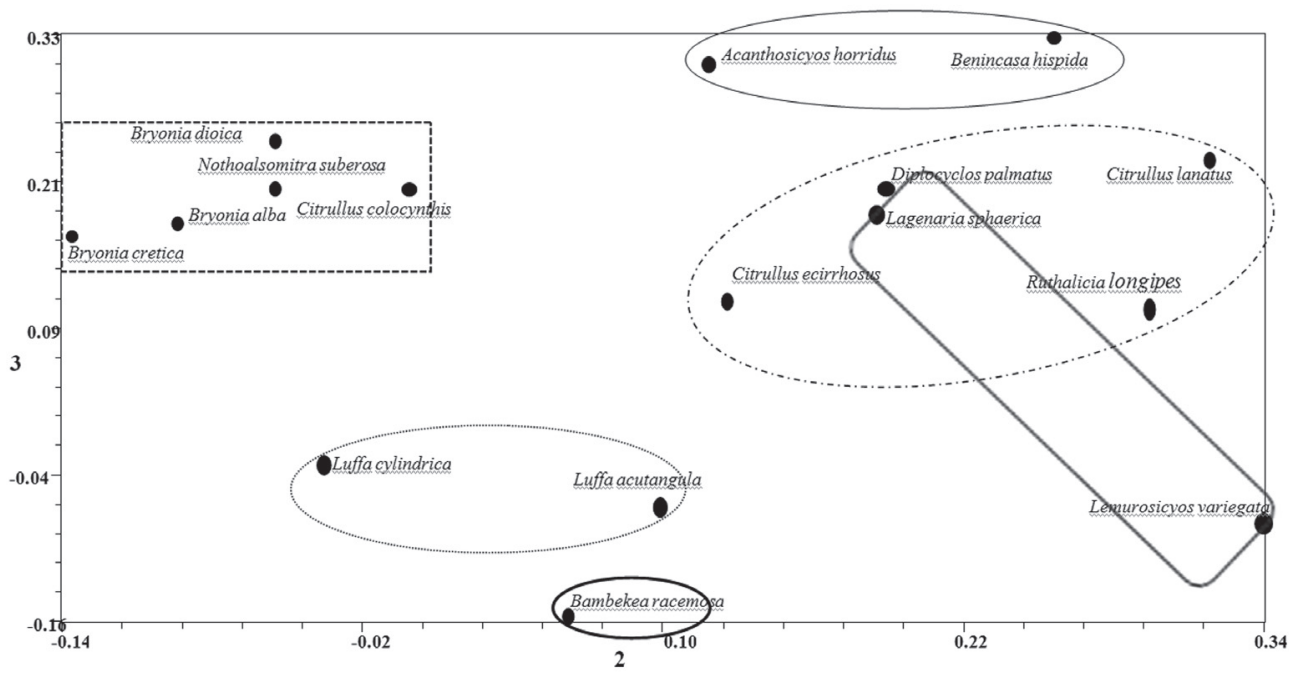

Figure 8. Scatterplot of the 16 OUTs plotted against the second principal coordinate by the third principal coordinate.

demonstrated that the tribe Benincaseae was not monophyletic and that the subtribes Benincasinae and Cucumerinae were highly polyphyletic.

Achigan-Dako (2008) investigated the phylogenetic analysis of 68 species of the tribe Benincaseae based on 127 nuclear rDNA ITS sequences and showed that the subdivision of the tribe into subtribes Benincasinae and Cucumerinae was not supported.

Our UPGMA and PCO results showed that the tribe Benincaseae was separated into four clusters and a branch. Within group B there was a close relationship with 0.50 similarity corresponding to group B including Lagenaria spaerica and Lemurosicyos variegata. Specializations in seed morphology include oblong to obovoid seeds; flat, dentate margin seed; arillated; isodiametric to polygonal epidermal cell shape; straight to slightly sinuous, raised, smooth to fine folded anticlinal boundaries; and flat to slightly convex periclinal cell walls.

Moreover, in group C (Diplocyclos palmatus, Citrullus lanatus, and C. ecirrhosus) there was a close relationship with about 0.45 similarity. They shared the same seed shape characters; arillated; raised, smooth to fine folds anticlinal cell wall and flat periclinal cell wall, but differed in seed wing and seed size; and their undulate to straight anticlinal cell wall.

Another branch of species was represented by Citrullus colocynthis, which separated from other species of Citrullus based on yellowish brown seed, not arillated, and smooth to fine folds in the periclinal cell wall.

Also, a branch of species represented by Nothoalsomitra subcerosa separated with a group of Bryonia based on ovoid seed shape, flat smooth seed surface, and irregular, polygonal epidermal cell shapes. Schaefer \& Renner (2011) 
defined Nothoalsomitra subcerosa, Luffa, and other genera in the separate tribe Sicyoeae.

Inside group F, there was a close relationship with 0.43 similarity including Acanthosicyos horridus, Benincasa hispida, and Ruthalicia longipes, based on the yellowish brown seeds; seed size large with $10-15 \mathrm{~mm} \times 5-8 \mathrm{~mm}$; elongate in one direction to isodiametric epidermal cell shape; straight to slightly sinuous, raised anticlinal boundaries; and a flat periclinal cell wall.

Our results are congruent with those of Walters \& Decker-Walters (1991), Chung et al. (2003), Kocyan et al. (2007), and Achigan-Dako (2008), which suggests that tribe Benincaseae is not a monophyletic group and that subtribe Benincasinae is highly polyphyletic; this is because we found the taxa from this tribe interspersed to both different clusters and with taxa from other tribes.

\subsubsection{Tribe Luffeae C. Jeffrey (2005) (group D)}

Inside this cluster (group D), two species of Luffa were recognized with 0.70 morphological similarity. These species can be clearly defined on the basis of various features: black seed, flat, compressed, seed large size $(10-14 \times 7-10 \mathrm{~mm})$, irregular to polygonal cells epidermal, undulate, raised anticlinal cell wall boundaries and flat periclinal cell walls. Luffa is distinct from other members of the tribe Benincaseae in several respects. For instance, these species produce fibrous fruits with operculate dehiscence and have racemose staminate flowers with three to five stamens and free petals, solitary pistillate flowers, and three to five parted tendrils (Heiser \& Schilling 1990). Likewise, all other genera of the Benincaseae have haploid chromosome numbers of 10,11 , or 12 , but all species of Luffa have the haploid number 13 (Whitaker 1933). Heiser \& Schilling (1988) investigated the phylogeny of the genus Luffa based on morphological characters and revealed two phyletic lines: one of them comprised Luffa cylindrical ( $L$. aegyptiaca) and L. acutangula, and the other included the rest of the species. Moreover, Walters \& Decker-Walters (1991) showed that three major evolutionary lineages within the Benincaseae and one major line included Luffa. In addition, Singh \& Dathan (1998) investigated the seed coat anatomy of the Cucurbitaceae and showed that Luffa differed from the rest of the Benincaseae and they elevated them to tribal rank. However, Telford (1982) placed it in the Benincaseae because of its globose synandrium with strongly sigmoid thecae. Kocyan et al. (2007) placed Luffa far from Benincaseae. Generally, these results agree with those of Heiser \& Schilling (1988), Walters \& Decker-Walters (1991), Jeffrey (2005), Kocyan et al. (2007), and Achigan-Dako (2008), which suggests that tribe Luffeae is a monophyletic group.

\subsubsection{Tribe Bryonieae Dumort. (1827) (group E)}

Inside this cluster (group E), three species of genus Bryonia (B. alba, B. cretica, and B.dioica), and two species from tribe Benincaseae (Nothoalsomitra subcerosa and Citrullus colocynthis) were recognized with 0.70 morphological similarity. These species can be clearly defined on the basis of various features: ovoid to obovoid seed, flat and smooth seed surface, irregular to polygonal cells epidermal, although Bryonia differed from the other in having seed with a narrow ridge, small seed size, and a straight to slightly sinuous, raised anticlinal cell wall.

Singh \& Dathan (1998) showed that Bryonia and Ecballium differed in their osteosclereids in the main mechanical layer, which were placed radially in the latter and obliquely in the former, and they segregated these two genera into distinct tribes. Current observations of seed coat can be diagnostic or indicative of phylogenetic relationships, and these results are in agreement with the phylogenetic results of Jobst et al. (1998), Chung et al. (2003), Schaefer \& Renner (2011), seed coat anatomy results of Singh \& Dathan (1998), isozyme by Walters et al. (1991) and morphology by Jeffrey $(1980 ; 2005)$, which suggests that tribe Bryonieae is a monophyletic group.

\section{Conclusions}

The structure of seed coats offers a set of characters useful for the taxonomy of the Cucurbitaceae. The present study showed that seeds of Cucurbitaceae display high diversity in shape, color, size, surface, epidermal cell characters, anticlinal cell wall boundaries, and periclinal cell wall; some species even have specialized structures. Seed coat morphology also provided some evidence for intrageneric classification and corresponded with the phylogenetic results of Chung et al. (2003), Kocyan et al. (2007), Achigan-Dako (2008), and Schaefer \& Renner (2011). Furthermore, current results support the monophyly of Bryonieae, Coniandreae, and Luffeae, as suggested by Chung et al. (2003), Jeffrey (2005), Kocyan et al. (2007), Achigan-Dako (2008), and Schaefer \& Renner (2011). Likewise, these analyses support previous biochemical and phylogenetic data, indicating that distinct lineages exist within the tribe Benincaseae and demonstrate that the tribe Benincaseae is not monophyletic and that subtribe Benincasinae is highly polyphyletic. Finally, seed coat analysis confirmed that developmental variation in seed characters is taxonomically useful, not only because it gives us a better understanding of sculpture development, but also because it allows us to formulate the taxonomy of Cucurbitaceae on the genera and tribal levels, and it is useful for constructing an identification key.

\section{Acknowledgments}

We are grateful to the Directors and Curators of the International Herbaria (K, E and CAIM) and Kew garden, Millennium seed bank for providing us with materials. 


\section{References}

Abdel Khalik KN. 2010. Seed coat morphology its systematic significance in Juncus L. (Juncaceae) in Egypt. Journal of Systematic and Evolution 48: 215-223.

Abdel Khalik KN. 2013. Systematic implications of seed coat diversity in some representatives of the genus Ipomoea (Convolvulaceae).Turkish Journal of Botany 37: 811-824.

Abdel Khalik KN, Hassan NS. 2012. Seed coat trichome micromorphology of Egyptian Fagonia (Zygophyllaceae) with emphasis on its systematic implication. Nordic Jornal of Botany 30: 116-126.

Abdel Khalik KN, Maesen LJGVD. 2002. Seed morphology of some tribes of Brassicaceae (implications for taxonomy and species identification for the flora of Egypt). Blumea 47: 363-383.

Achigan-Dako GE. 2008. Phylogenetic and genetic variation analyses in cucurbit species (Cucurbitaceae) from West Africa: definition of conservation strategies. Göttingen, Cuvillier Verlag.

Attar F, Keshvari A, Ghahreman A, Zarre S, Aghabeigi F. 2007. Micromorphological studies on Verbascum (Scrophulariaceae) in Iran with emphasis on seed surface, capsule ornamentation and trichomes. Flora 202: 169-175.

Barthlott W. 1981. Epidermal seed surface characters of plants: systematic applicability and some evolutionary aspects. Nordic Jornal of Botany 1:345-355.

Barthlott W. 1984. Microstructural features of seed surface. In: Heywood VH, Moore DC. (eds.) Current Concepts in Plant Taxonomy. London: Academic Press. pp. 95-105.

Chung SM, Decker-Walters DS, Staub JE. 2003. Genetic relationships within the Cucurbitaceae as assessed by consensus chloroplast simple sequence repeats (ccSSR) marker and sequence analyses. Canadian Journal of Botany 81: 814-832.

Clarke AC, Burtenshaw MK, McLenachan PA, Erickson DL, Penny D. 2006. Reconstructing the origins and dispersal of the Polynesian bottle gourd (Lagenaria siceraria). Molecular Biololgy and Evolution 23: 893-900.

Davitashvili N, Karrer G. 2010. Taxonomic importance of seed morphology in Gentiana (Gentianaceae). Botanical Journal of the Linnean Society 162: 101-115.

Decker-Walters DS, Chung SM, Staub JE. 2004. Plastid sequence evolution: A new pattern of nucleotide substitutionns in the Cucurbitaceae. Journal of Molecular Evolution 58: 606-614.

Erickson DL, Smith BD, Clarke AC, Sandweiss DH, Tuross N. 2005. Asian origin for a 10,000-year-old domesticated plant in the Americas. Proceedings of the National Academy of Sciences 102: 18315-18320.

Hassan NS, Abdel Khalik KN. 2014. The Systematic significance of the seed morphology of the genus Veronica L. (Plantaginaceae) with special reference to the Egyptian Taxa. Journal of Systematics and Evolution 52: 215-230.

Heiser CB, Schilling EE. 1988. Phylogeny and distribution of Luffa (Cucurbitaceae). Biotropica 20: 185-191.

Heiser CB, Schilling EE. 1990. The genus Luffa: a problem in phytogeography. In: Bats DM, Robinson RW, Jeffrey C. (eds.) Biology and utilization of the Cucurbitaceae. Ithaca, Cornell University Press. p. 120-133.

Heywood VH. 1971. Scanning electron microscopy: systematic and evolutionary applications. London, Academic Press.

Hooker JD. 1867. Cucurbitaceae. In: Bentham G, Hooker JD. (eds.) Genera Plantarum 1. London, Reeve \& Co. p. 816-841.

Jeffrey C. 1980. A review of the Cucurbitaceae. Botanical Journal of the Linnean Society 81: 233-247.

Jeffrey C. 1990. Systematics of the Cucurbitaceae, an overview. In: Bates DM, Robinson RW, Jeffrey C. (eds.) Biology and Utilization of the Cucurbitaceae. Ithaca, Cornell Univ. Press. p. 3-9.

Jeffrey C. 2005. A new system of Cucurbitaceae. Botanichiskii Zhurnal 90: 332-335.
Jobst J, King K, Hemleben V. 1998. Molecular evolution of the internal transcribed spacers (ITS1 andITS2) and phylogenetic relationships among species of the family Cucurbitaceae. Molecular phylogenetics and Evolution 9: 204-219.

Johnson LA, Huish KH, Porter JM. 2004. Seed surface sculpturing its systematic significance in Gilia (Polemoniaceae) and segregate genera. International Journal of Plant Science 165: 153-172.

Kocyan A, Zhang LB, Schaefer H, Renner SS. 2007. A multi-locus chloroplast phylogeny for the Cucurbitaceae and its implications for character evolution and classification. Molecular Phylogenetics and Evolution 44: 553-577.

Moazzeni H, Zarre S, Al-Shehbaz IA, Mummenhoff K. 2007. Seed coat microsculpturing and its systematic application in Isatis (Brassicaceae) allied genera in Iran. Flora 202: 447-454.

Mostafavi G, Assadi M, Nejadsattari T, Sharifnia F, Mehregan I. 2013. Seed micromorphological survey of the Minuartia species (Caryophyllaceae) in Iran. Turkish Journal of Botany 37: 446-454.

Okoli BE, Onofeghara FA. 1984. Distribution and morphology of extra floral nectaries in some Cucurbitaceae. Botanical Journal of the Linnean Society 89: 153-164.

Rizk RMH. 2001. Cytotaxonomic Studies on the Egyptian Taxa of Cucurbitaceae. PhD Thesis, Mansoura Univ., Egypt.

Schaefer H, Renner SS. 2011. Phylogenetic relationships in the order Cucurbitales and a new classification of the gourd family (Cucurbitaceae). Taxon 60: 122-138.

Simpson MG. 2010. Plant systematics, 2nd. edn. London, Academic Press. Singh D, Dathan ASR. 1998. Morphology and Embryology. In: Nayar NM, More TA. (eds.) Cucurbits. Enfield, Science Publishers, Inc. p. 67-84.

Singh D, Dathan ASR. 2001. Development and structure of seed coat in the Cucurbitaceae and its implications in systematics. In: Chauhan SVS, Chaturvedi SN (Eds.), Botanical Essays:Tribute to Professor Bahadur Singh. Printwell Publishers Distributors, Jaipur, pp. 87-114.

Stuessy TF. 1990. Plant Taxonomy: The Systematic Evaluation of Comparative Data. New York: Columbia University Press.

Telford IR. 1982. Cucurbitaceae. Flora of Australia 8: 158-198, 205.

Teppner H. 2004. Notes on Lagenaria and Cucurbita (Cucurbitaceae) -review and new contributions. Phyton 44: 245-308.

Vossen HAMVD, Denton OA, El Tahir IM. 2004. Citrullus lanatus (Thunb.) Matsum. and Nakai. In: Grubben GJH, Denton OA. (eds.) Plant Resources of Tropical Africa 2. Vegetables. Wageningen, PROTA Foundation, Wageningen, Netherlands/ Backhuiser Publishers, Leiden /CTA. p. 185-191.

Walters TW. 1989. Historical overview on domesticated plants in China with special emphasis on the Cucurbitaceae. Economic Botany 43: 297-313.

Walters TW, Decker-Walters DS. 1991. Determination and interpretation of Comigrating allozymes among genera of the tribe Benincaseae (Cucurbitaceae). Systematic Botany 16: 30-40.

Werker E. 1997. Seed Anatomy: Handbook of Botany. Vol. 10, Part 3. Berlin, Borntraeger Press.

Whitaker TW. 1933. Cytological and phylogenetic studies in the Cucurbitaceae. Botanical Gazette 94: 780-790.

Whitaker TW, Davis GN. 1962. Cucurbits - Botany, cultivation and utilization. London, Leonard Hill.

Wilde WJJO, Duyfjes BEE. 2006a. Redefinition of Zehneria and four new related genera (Cucurbitaceae), with an enumeration of the Australasian and Pacific species. Blumea 51: 1-88.

Wilde WJJO, Duyfjes BEE. 2006b. Review of the genus Gymnopetalum (Cucurbitaceae). Blumea 51: 281-296.

Wilde WJJO, Duyfjes BEE. 2006c. Scopellaria, a new genus name in Cucurbitaceae. Blumea 51: 297-298. 